Summer 2013

\title{
The Impact of the Economic Downturn on Women Lawyers in the United States
}

Cynthia Fuchs Epstein

Graduate Center, City University of New York, cepstein@gc.cuny.edu

Abigail Kolker

Follow this and additional works at: https://www.repository.law.indiana.edu/ijgls

Part of the Civil Rights and Discrimination Commons, Labor and Employment Law Commons, Law and Economics Commons, Law and Gender Commons, Law and Society Commons, and the Legal Profession

Commons

\section{Recommended Citation}

Epstein, Cynthia Fuchs and Kolker, Abigail (2013) "The Impact of the Economic Downturn on Women Lawyers in the United States," Indiana Journal of Global Legal Studies: Vol. 20 : Iss. 2 , Article 20.

Available at: https://www.repository.law.indiana.edu/ijgls/vol20/iss2/20

This Symposium is brought to you for free and open access by the Law School Journals at Digital Repository @ Maurer Law. It has been accepted for inclusion in Indiana Journal of Global Legal Studies by an authorized editor of Digital Repository @ Maurer Law. For more information, please contact rvaughan@indiana.edu.

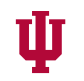

JEROME HALL LAW LIBRARY

INDIANA UNIVERSITY

Maurer School of Law
Bloomington 


\title{
The Impact of the Economic Downturn on Women Lawyers in the United States
}

\author{
CYNTHIA FuCHS EPSTEIN \& ABIGAIL KOLKER*
}

\begin{abstract}
Although women have made considerable inroads in the legal profession over the past four decades, a review of their distribution in various types of practice in the United States shows that, compared to their male colleagues, they have been affected disproportionately by the recent economic downturn, although not in every sphere of the profession. This study reviews research, articles in the legal press, and online blogs that report women's access to equity partnerships has been stalled, their representation in part-time employment has increased, and they are disproportionately recruited or diverted to positions as staff or contract attorneys. Women's access to prime legal jobs has diminished, and they face employment strategies that no longer favor diversity in the profession. Furthermore, the recession has had an impact on the hiring and retention of minority lawyers although firms feel pressure to retain them. There is some indication of growing opportunity for women as corporation counsels in large corporations. There is also some indication that a smaller proportion of women are applying for and entering law schools.
\end{abstract}

\section{INTRODUCTION}

Although women now figure among the top lawyers in some very august spheres, indicating that they are no longer the anomaly they once were and that a number of them wield considerable power, there is some indication that women just entering the profession are facing limits to their participation and mobility. This stems from the economic

* Lisa Ackerly Hernandez contributed substantially to this paper. We are also grateful to the commentators, Gabriele Plickert, Fiona Kay, Joyce Sterling, Nancy Reichman, and Carroll Seron, at the session "Cross-National Comparison of Gender in Professional Legal Work and Work Life Balance" at the Law and Society Association International Meeting in Honolulu, Hawaii, June 7, 2012.

Indiana Journal of Global Legal Studies Vol. 20, Issue 2 (2013)

(C) Indiana University Maurer School of Law 
downturn in 2008 and the more basic restructuring and changing ethos of the legal profession.

A number of high-profile women lawyers have done extraordinarily well in both the international and national legal spheres in the past few years. This is critically important for creating expectations for women's achievement and undermining persistent stereotypes regarding the inability of women to compete with men and perform at the same levels of excellence as men in the profession.

Hillary Rodham Clinton, a former practicing lawyer, recently completed a term as Secretary of State of the United States and was also a serious contender for the Democratic Party's 2008 presidential nomination. Once ridiculed for her changing hair styles and other inconsequential behaviors, the press no longer comments on her appearance, but rather on her policies.

In Europe and around the world, Christine LaGarde stands out as the Managing Director of the International Monetary Fund. A lawyer by training and the first female chair of the giant international law firm Baker \& McKenzie, LaGarde plays a prominent role in international finance and has had a very high profile during the European debt crises.

And, of course, for the first time in history, there are three women on the Supreme Court of the United States, following President Barak Obama's appointments of Sonia Sotomayor and Elena Kagan to join Ruth Bader Ginsburg.

These appointments are an indicator of the heightened acceptance of women by a profession (and the public) that has historically been antagonistic to their entry. But at the same time, women lawyers have had to confront the consequences of a changing economy and a profession that has become much more competitive and unpredictable. Some of the changes are due to ongoing transformations in the legal profession, while some are due to the fallout from the economic recession in 2008 and ongoing fears about the economy.

Analysts of the profession, such as Marc Galanter and William Henderson, ${ }^{1}$ Joyce Sterling and Nancy Reichman, ${ }^{2}$ David Wilkins, ${ }^{3}$ and Eli Wald, ${ }^{4}$ have written extensively on transformations within the legal

1. See, e.g., Marc Galanter \& William Henderson, The Elastic Tournament: A Second Transformation of the Big Law Firm, 60 STAN L. REV. 1867 (2008).

2. See, e.g., Joyce S. Sterling \& Nancy Reichman, So, You Want to Be a Lawyer? The Quest for Professional Status in a Changing Legal World, 78 FORDHAM L. REv. 2289 (2010).

3. See, e.g., David B. Wilkins, Team of Rivals? Toward a New Model of the Corporate Attorney-Client Relationship, 78 FoRDHAM L. REV. 2067 (2010).

4. See, e.g., Eli Wald, Glass Ceilings and Dead Ends: Professional Ideologies, Gender Stereotypes, and the Future of Women Lawyers at Large Law Firms, 78 FORDHAM L. REv. 2245 (2010). 
profession, especially those within the top law firms in the United States and abroad (for example, the British "Magic Circle"). 5 These firms have deviated from their rather staid and predictable patterns of hiring, training, and elevating associates to become partners in their firms. Indeed, according to Wald, they are experiencing an ideological shift. ${ }^{6}$ While the old "Tournament of Lawyers" model ${ }^{7}$ was not very accommodating to women, persons of color, or persons of non-Protestant religious backgrounds, it has become more accommodating over time. The new social structure of the profession may be problematic in other ways, however.

Of course, law students from the top private and public university law schools expecting placement in the top firms in the country are still better positioned than students whose grades are not exemplary or those who have graduated from less prestigious schools. But today, all graduates coming out of law schools, at a time when economies all over the world are facing severe challenges, are having considerable trouble finding the kind of employment they had hoped to attain and, for which, they have taken on considerable debt.

This has been a period of declining hiring rates, downsizing, and decreasing expenditures on diversity and retention programs that may be having a particularly negative impact on women attorneys in law firms. Part-time and contract attorneys, many of whom are women, face additional struggles. Further, public interest firms are suffering from a decrease in their contributions and revenues from public institutions. ${ }^{8}$ There are repercussions for lawyers belonging to minority groups as well. Major newspapers such as the New York Times and the Wall Street Journal, the legal press, and legal blogs (e.g. Ms. JD, Above the Law) have focused on the bad news, leading to a culture of despair among many lawyers and aspiring lawyers. ${ }^{9}$

5. Taking the Magic Abroad: London's Big Law Firms are Expanding Their Global Footprints, ECONOMIST (July 7, 2012), http://www.economist.com/node/21558320.

6. See generally Wald, supra note 4.

7. See generally MARC GaLANTER \& ThOMAS PALAY, TOURNAMENT OF LAWYERS: THE TRansformation OF THE BIg LAW Firm (1991); CYNTHIA FUCHS EPSTEIN, WOMEN IN LAW (Quid Pro Books 2012) (1981); ERWIN SMIGEL, THE WALL STREET LAWYER (1964).

8. See Dave Collins, Lawyers Across US Urged to Give More Free Services, ASSOCIATED PRESS, Aug. 20, 2012, available at http://cnsnews.com/news/article/lawyersacross-us-urged-give-more-free-services (emphasizing that pro bono work by large law firms has declined in the past few years amid downsizing because of the economy).

9. E.g., Lincoln Caplan, An Existential Crisis for Law Schools, N.Y. TIMES, July 15, 2012, at SR10; Andrew Ross Sorkin, Big Law Steps into Uncertain Times, N.Y. TIMES, Sept. 25, 2012, at F1, F9; Stanley Fish, The Bad News Law Schools, N.Y. TIMES OPINIONATOR (Feb. 20, 2012, 9:00 PM), http:/opinionator.blogs.nytimes.com/2012/02/20/ the-bad-news-law-schools/. 
It is important to note that any measurement of women's or men's participation in law schools and later as practicing lawyers must be regarded in the context of a legal profession that was in a state of transformation even before the economic crisis. But many changes were accelerated by the downturn. Not only were large and small firms affected, but other sectors of the law as well, such as practices in public interest, the government, and corporations. ${ }^{10}$

Just after the fall of the stock market in 2008, many institutions were scrambling to deal with the decline. This meant fewer people engaging in enterprise, negotiating deals, making contracts, and otherwise responding to a plunging economy. Law firms were greatly affected and so were other legal organizations dependent on funding provided by a healthier economy. Only some sectors with specialties such as bankruptcy and labor law did well.11 There are troublesome signs that the recession, combined with lower hiring rates, downsizing, and a decrease in professional development staff and related expenditures, has the potential to undo years of incremental advances toward diversity in law firms and hopes for a restructuring of the profession to make it more congenial to female and male attorneys seeking to live more balanced work and family lives. The profession was already undergoing restructuring prior to the downturn. Some sectors were merging or downsizing, and individual, rather than firm, relationships were becoming important. According to Wilkins, long-term relationships between firms and large corporate clients have been on the decline for some time, and clients place more emphasis on the reputation and experience of individual lawyers rather than particular firms. ${ }^{12}$ This may have had an impact on women's opportunities because a disproportionate number of them were somewhat new to the profession and would not have been able to benefit from long-established personal relationships with corporate clients. On the other hand, women specialists could have profited if their clients appreciated their particular expertise.

As we shall note, women lawyers suffered disproportionally to men in particular ways during the recession. First, the proportion of women among all lawyers declined between 2008 and 2011. Although the decrease was slight, it represents a reversal of what had been in recent decades a steady increase in minority and female representation in law

10. Id.

11. This information was given to author via a personal communication with attorney Meg Thering.

12. See Wilkins, supra note 3 . 
firms. ${ }^{13}$ Women made up 38.3 percent of all lawyers in $2008 .{ }^{14}$ By 2011 , their number had gone down to 34.4 percent of the total. ${ }^{15}$ These losses did not happen immediately after the economic downturn. According to the National Association for Legal Career Professionals (NALP), the overall representation of women declined slightly further in 2011 as compared with 2010.16 However, there are restraints on the downward path faced by women, which can be attributed to changes in a culture that has come to value the participation of formerly disadvantaged categories of people.

This article is organized into six sections. First, we consider the impact of the recession on women's entry into the profession as law students. Second, we examine female stratification in law firms. We not only examine the proportion of female partners, but we also take an in-depth look at how restructuring of firm partnerships has affected women. We also look at the proportions of female associates, staff attorneys, of-counsel lawyers, and general counsels. We note that women may be being taken off the partnership track and relegated to these other positions. In the third section, we examine the impact of the recession on the availability and security of part-time positions for women. In the fourth section, we examine female compensation at every level of the law firm and how the recession has affected the gender pay gap. In section five, we examine the recession's effect on the termination of women lawyers, the hiring of summer associates, and their later employment in firms where they previously worked. Then, we examine the many effects of the recession on minority women, from entry to law school and the profession to their retention and mobility. Finally, we determine the impact of the recession on women in the judiciary.

\section{LAW SCHOOLS}

Until the opening of the profession to women in the 1970s, female law school applicants accounted for fewer than 10 percent of the total

13. See Press Release, NALP, Law Firm Diversity Among Associates Erodes in 2010, at 1 (Nov. 4, 2010), http://www.nalp.org/2010lawfirmdiversity.

14. Median Weekly Earnings of Full-Time Wage and Salary Workers by Detailed Occupation and Sex, EMP'T \& EARNINGS ONLINE (U.S. Dep't of Labor, Bureau of Labor Statistics, D.C.), Jan. 2010, at 251, 252, ftp://ftp.bls.gov/pub/special.requests/f/aa2008/pdf/ cpsaat39.pdf.

15. Median Weekly Earnings of Full-Time Wage and Salary Workers by Detailed Occupation and Sex, EMP'T \& EARNINGS ONLINE (U.S. Dep't of Labor, Bureau of Labor Statistics, D.C.), Jan. 2012, at 1, 3, http://www.bls.gov/cps/aa2011/cpsaat39.pdf.

16. Press Release, NALP, Law Firm Diversity Wobbles: Minority Numbers Bounce Back While Women Associates Extend Two-Year Decline 1 (Nov. 3, 2011), http://www.nalp.org/2011_law_firm_diversity [hereinafter Diversity Wobbles]. 
recorded. ${ }^{17}$ But women gradually moved toward equity in law school admissions. Although their status in the profession has improved markedly, women today, along with men, appear to be reconsidering whether the price of a law degree is worth the time and money. ${ }^{18}$

Practitioners in their sixties and beyond may regard participation of women in the legal profession in the United States as relatively new. Grandmothers of the women coming out of law school today can remember how hard it was for women to be accepted into law schools, and, for the few who passed that barrier, the difficulty they faced getting jobs as lawyers in firms of any size. ${ }^{19}$ However, their mothers' generation faced an entirely different environment, as law schools and law firms changed their discriminatory policies after a number of successful challenges in the courts, allowing women to find jobs in the profession.

Starting in the 1970s, and through the 1980s and 1990s, there was a steady increase in the number of women who enrolled in law school. At the peak of the trend in 2002, they constituted 49.05 percent of all law students. ${ }^{20}$ However, since 2002, for most years they were a bit less than half of all law students. ${ }^{21}$ In 2006, before the economic recession, 48.1 percent of J.D.s were awarded to women, ${ }^{22}$ but by 2009 , women's share of law degrees had decreased to 45.9 percent. ${ }^{23}$ Nearly all of the top law schools display similar numbers. ${ }^{24}$

There are many explanations for the gender discrepancy in women law school applicants during the earlier decades of the twentieth century. Of course, there had been a historic characterization of law as a

17. See EPSTEIN, supra note 7, at 53.

18. In the United States, a legal education takes three years of full-time study, with an annual tuition of about $\$ 50,000$ at top schools.

19. See EPSTEIN, supra note 7, at 49-53, 79.

20. Vivia Chen, Women Spurn Law Schools, CAREERIST (May 16, 2011, 2:30:09 PM), $\mathrm{http} / / /$ thecareerist.typepad.com/thecareerist/2011/05/fewer-women-at-nations-lawschools.html.

21. Ann Farmer, Are Young Women Turning Their Backs on Law School?, 18 PERSP. 4 (2010).

22. ABA Comm'n on Women in the Profession, A Current Glance at Women in THE LAW 2007, at 2 (2007), available at $\mathrm{http}: / / \mathrm{www}$.americanbar.org/content/dam/aba/mig rated/women/reports/CurrentGlanceStatistics2007.authcheckdam.pdf GLANCE 2007].

[hereinafter

23. ABA Comm'n on Women in the Profession, A CuRrent Glance at Women in THE LAW 2011, at 3 (2011), available at $\mathrm{http}: / / \mathrm{www}$.americanbar.org/content/dam/aba/ uncategorized/2011/cwp_current_glance_statistics_2011.authcheckdam.pdf [hereinafter GLANCE 2011].

24. Chen, supra note 20 (explaining that the percentage of female enrollment at top law schools ranged from $42.6 \%$ at New York University to $49.3 \%$ at Yale University, with the exception of U.C. Berkeley which had an enrollment of 52.9\%). 
"male" profession. Not only was this a common attitude, but also the profession's male leaders actively fought to maintain limits on the participation of women, both by refusing them entry to law schools and by denying them employment when they managed to attain a legal education. ${ }^{25}$

At the time the recession hit, there was an increase in the number of individuals who took the Law School Admission Tests (LSAT) and applied to law school. In 2009-2010, the number of people taking the LSAT increased by as much as 19.8 percent. ${ }^{26}$ The recession is believed to have motivated people to get advanced degrees for a number of reasons, including the hope to better compete for a smaller number of jobs and because it became easier to get student loans under the U.S. government's stimulus bill. ${ }^{27}$ However, since 2010, the total amount of people taking the LSAT has decreased by 25 percent, reflecting both the fact that lawyers were hit hard at the beginning of the recession and that, today, a law degree no longer offers the same degree of economic security it did in the past, especially considering the debt many students accrue. ${ }^{28}$

To explain why the recession has deterred women more than men from entering law school, we turned to legal blogs and online magazines to provide insight on the reasoning of young people contemplating a career in the legal world. In the publication Perspectives: A Magazine for and About Women Lawyers, journalist Ann Farmer hypothesized that the number of female applicants has decreased because women are more afraid to go into debt than are men. ${ }^{29}$ She also suggests that men are more motivated than women to become lawyers because they care more about earning high incomes. ${ }^{30}$ It also could be that women are drawn to other fields. On The Careerist law blog, Vivia Chen posits that women are aware of glass ceilings and of the demand for long hours and work weeks and, therefore, do not regard legal careers to be as attractive as men do. ${ }^{31}$ Press attention to books and articles about the problems women face in managing high-level careers and motherhood, such as Anne-Marie Slaughter's essay, Why Women Still Can't Have it All in

25. EPSTEIN, supra note 7 , at 49-53, 79-80.

26. Farmer, supra note 21 , at 6.

27. See id.

28. See David Segal, For 2nd Year, a Sharp Drop in Law School Entrance Tests, N.Y. TIMES, Mar. 20, 2012, at B1.

29. See Farmer, supra note 21 , at 7 .

30. Id. at 5 .

31. Vivia Chen, Recession Tough on Women Lawyers, CAREERIST (Nov. 9, 2010, 4:03:53 AM), http:/thecareerist.typepad.com/thecareerist/2010/11/nawl-report-.html (making such a suggestion in a private version of the blog entry accessible only to the authors and on file with them). See also Farmer, supra note 21, at 5. 
The Atlantic Magazine, may be contributing to young women's fears about combining high-demand careers with family. ${ }^{32}$

It is certainly not their ability! Once in law school, women have done very well. From the time they were first admitted to law schools, they have equaled men in performance. ${ }^{33}$ Although a well-known study by Lani Guinier's student Ann Barlow reported that, at the University of Pennsylvania Law School, women performed less well than men due to an unpleasant scholastic and social environment, ${ }^{34}$ this was by no means typical. In fact, men and women have been found to perform about the same in law school. ${ }^{35}$ Indeed, women graduate with higher grade point averages (GPAs) than their male counterparts. ${ }^{36}$

In fact, by an important measure-participation in law journals-women seem to have improved their record considerably over the years. A 2008-2010 study conducted by researchers for the blog Ms. $J D$ examined the proportion of men and women who were on the editorial boards of general interest law reviews at the country's top fifty law schools. The study found that female membership on law review editorial boards (44.3 percent) and women in positions of law review leadership (46.2 percent) roughly corresponded to the percentage of female law school enrollment. ${ }^{37}$ Further, about 33 percent of editors-in-chief were women. ${ }^{38}$

Today, according to articles we have examined on a number of legal blogs, such as The Careerists, WSJ Law Blog, and Law360, women can and should become lawyers on the same basis as men. Thus, women are often angered and surprised to encounter prejudices or the belief that the lower percentage of women in the profession's elite domain reflects

32. Ann-Marie Slaughter, Why Women Still Can't Have It All, ATLANTIC, July-Aug. 2012, available at http://www.theatlantic.com/magazine/archive/2012/07/why-women-stillcant-have-it-all/309020\%.

33. See generally EPSTEIN, supra note 7.

34. See Lani Guinier, Of Gentlemen and Role Models, 6 BERKELEY WOMEN's L.J. 93,96 n.6 (1990).

35. Although Guinier's study found that women do less well in law school, most other reports indicate that women have higher GPAs than men. A study by Timothy $T$. Clydesdale observed no statistically significant grade point average (GPA) in the first year and a significant female advantage in final GPA. Timothy T. Clydesdale, A Forked River Runs Through Law School: Toward Understanding Race, Gender, Age, and Related Gaps in Law School Performance and Bar Passage, 29 L. \& Soc. INQUIRY 711-68 (2004). See also Ann Bartow, Still Not Behaving Like Gentlemen, 49 U. KAN. L. REv. 809 (2001).

36. Carrie Corcoran \& Margaret C. Thering, Women's Bar association of THE STATE OF NEW YORK 2012 CONVENTION: LABOR AND EMPLOYMENT LEGAL Issues AFFECTING FEMALE ATTORNEYS 5 (2012).

37. Women on Law Review: A Gender Diversity Report, Ms. JD (Aug. 23, 2010, 9:15 AM), http://ms-jd.org/files/ms._jd_Ir_8.23.2010.pdf.

38. Id. 
their own choices (e.g. "work-life balance") rather than those of the professional gatekeepers. The writers of the blogs find that inequality is especially shocking because the basis of comparison has been performance in law school, where men and women have been on par. ${ }^{39}$

Of course there is an ever-changing backdrop to the figures cited above. Only 55 percent of 43,735 graduates of law schools in 2011 had a law-related job nine months after graduation, according to a study done by Professor William Henderson of the Indiana University Maurer School of Law as reported by Lincoln Caplan in the New York Times. ${ }^{40}$ According to the report, 28 percent were unemployed or underemployed.41 And although at the twenty law schools with the highest employment of graduates, 83 percent were working as lawyers, for the bottom of the group it was 31 percent. The "numbers are far worse than job data going back a generation," according to Caplan. ${ }^{42}$ Class of 2011 graduates from the "most popular-for-hiring" fifty schools did even worse than 2010 graduates, demonstrating that even as the economy began to rebound, firms were reluctant to increase associate hiring. ${ }^{43}$ Clearly, this background has not provided a hospitable environment for women entering the profession.

\section{STRATIFICATION IN FIRMS AND CONSEQUENCES FOR WOMEN LAWYERS}

When examining the recession's effects on new hires, terminations, and women's career advancement and compensation, we focus on private law firms because currently more than 50 percent of women lawyers practice in this sector. ${ }^{44}$ The other half work for business and industry (12 percent), for the government (13.5 percent), in judicial clerkships (11.3 percent), in public interest ( 7.8 percent), or in academic institutions (2.3 percent). ${ }^{45}$ As women were recruited equally with men in the United States, the hope was that they would move up the ladder equitably. Of course, for many years, women lawyers were on average much younger than the men in the profession and, therefore, did not have the experience and human capital that men had. By now it could

39. See Clydesdale, supra note 35.

40. Caplan, supra note 9 , at SR10.

41. Id.

42. Id.

43. Karen Sloan, It's Tough Out There, NAT'L L.J. (Feb. 27, 2012), http://www.law.com/jsp/nlj/PubArticleNLJ.jsp?id=1202543428380\&Its_tough_out_there.

44. Women in Law in the U.S., CATALYST (Mar. 11, 2013), http://www.catalyst.org/publi cation/246/women-in-law-in-the-us [hereinafter Women in Law].

45. Id. 
be expected that women would advance. Yet, they continue to be markedly underrepresented in law firm leadership.

\section{A. Firm Restructuring of the "Partner" Label}

During the economic downturn, women suffered a decline in achievement markers of professional success. One of the most common yardsticks for female advancement in the legal profession is the percentage of women partners. Beginning in the $1990 \mathrm{~s}$, women made slow and steady progress in achieving partnership. ${ }^{46}$ In $2008,18.7$ percent of partners were women, and the proportion has risen since then, so that by 2013, approximately 19.9 percent of partners were women. $^{47}$ Further, a 2012 report by the New York City Bar revealed that at member firms that committed themselves to diversity goals, women comprised 18.3 percent of partners (although that figure dipped to 17.8 percent and 17.5 percent in 2009 and 2010 , respectively). ${ }^{48}$

However, the total percentages may be deceiving. The structure of law firms is much more complicated today than it was in the past. Partnerships are now graded, which was not the case when most top law firms followed the classic Cravath model, in which all partnerships were at the same level. ${ }^{49}$ In the past, most firms on the American Lawyer 250 list made a simple distinction between associates and partners, but now many firms have instituted "two-tier" or "multi-tier" levels of partnership. In traditional one-tier firms, partners owned equity in the firm and were compensated on the basis of their equity investment. Today, in two-tier firms, in addition to equity partners, nonequity partners are paid a fixed annual salary with bonuses based on performance, and they have less power, if any, in the overall governance of the firm. ${ }^{50}$ Further, some firms have created a third distinction among the partners, that of fixed-income equity partners.

46. ABA COMM'N ON WOMEN IN the PROFEssion, A CURRENT GLANCE AT WOMEN IN THE LAW 6 (2012), available at http://www.americanbar.org/content/dam/aba/marketing /women/current_glance_statistics_2012.authcheckdam.pdf. See also Employment Patterns 1999-2010, NALP (Aug. 2011), http://www.nalp.org/employmentpatterns1999-2010.

47. Women in Law, supra note 44.

48. Lisa D'AnNolfo LeVey \& AMY MCPherson, N.Y.C. Bar Ass'N, NeW York City BAR 2011 DIVERSITY BENCHMARKING STUDY: A REPORT TO SIGNATORY LAW FIRMS 3 (2012), available at $\mathrm{http}: / / \mathrm{www} . n y c b a r . o r g / i m a g e s /$ stories/pdfs/diversity/2011_law_firm_diversity_ benchmarking_report.pdf.

49. See generally SMIGEL, supra note 7, at 114-16.

50. THE NAT'L ASS'N OF WOMEN LAWYERS \& THE NAWL FOUND., REPORT OF THE THIRD ANNUAL National SURVeY on RETENTION AND PROMOTION OF WOMEN IN LAW Firms 10 (2008) [hereinafter NAWL 2008], available at http://nawl.timberlakepublishing.com/files 12008_Survey_Report_FINAL_as\%20of\%2011-10-08.pdf. 
These lawyers are required to contribute capital to the firm when they are named as a partner, but are paid on a fixed-income basis, not sharing an equal percentage of the firm profits. ${ }^{51}$ This limited financial arrangement "significantly strains the meaning of the term equity partner." 52 This is, of course, a departure from a time when all partners shared equally. ${ }^{53}$ According to a 2011 report by the National Association of Women Lawyers (NAWL) of the nation's largest 200 law firms, 28 percent were one-tier, 60 percent were two-tier, and 13 percent were multi-tier. ${ }^{54}$ The movement away from one-tier firms increased during the recession. This is a big change from 2008, when 31 percent of firms were one-tier and 54 percent were two-tier. ${ }^{55}$ Firms have employed this structural mechanism to cope with the economic downturn. ${ }^{56}$

Of course, it is useful for firms, and for the lawyers within firms, to have the title of "partner" even if the title does not have the same meaning it had in the past and does not bring the same rewards. For one thing, the title elevates the status of the lawyer working with clients, and, for another, it permits billing at a higher rate. Further, because many women and minority lawyers achieve partnership status only at the nonequity level, it makes the firm's statistics look better regarding the inclusion of women and ethnic minorities. This is because women-women of color in particular-are more often excluded from the upper echelon. As the public has become more aware of this "partner" label distinction, firms that use a multi-tier structure further obscure gender and racial partnership inequalities.

We shall now explore the different types of partnerships and note where women partners are clustered. As we note, women are more successful in one-tier partnership firms than in two-tier or multi-tier firms. ${ }^{57}$ We speculate that this is because one-tier partnership gives everyone in that category the same rights.

51. Id.

52. Id.

53. See generally GALANTER \& PALAY supra note 7; SMIGEL, supra note 7.

54. Barbara M. Flom \& StePhanie A. SCHARF, THE NAT'l AsS'N OF WOMEN LaWyers \& THE NAWL Found., REPORT OF THE Sixth ANNUAL National SuRvey on RETENTION AND PROMOTION OF WOMEN IN LAW FTRMS 11 (2011) [hereinafter NAWL 2011], available at http://nawl.timberlakepublishing.com/files/NAWL\%202011\%20Annual\%20Survey\%20R eport\%20FINAL\%20Publication-ready\%2011-9-11.pdf.

55. NAWL 2008, supra note 50, at 10.

56. V. Dion Haynes, Rethinking Legal Fees For Lean Times, WASH. PoST, Oct. 20, 2008, at D01.

57. NAFE \& FLEX-TIME LAWYERS, EXECUTIVE SUMMARY: BEST LAW FIRMS FOR WOMEN 2011, at 8 (2011), available at http://www.wmmsurveys.com/2011_NAFE_and_Flex-Time_ Lawyers_Best_LawFirms_for_Women\%20Executive\%20Summary.pdf. 


\section{B. Equity Partners}

The most prestigious, powerful, and highly-compensated position in a U.S. law firm is that of the equity partner. Lawyers in this category share equally in the profits of the firm. Women account for just 15 percent of equity partners, a statistic that has remained basically unchanged for the past six years. ${ }^{58}$ Of the nation's largest 250 firms, only five firms report that women account for more than 25 percent of equity partners. ${ }^{59}$

Female partners are less likely to be equity partners than male partners: 47 percent of female partners are equity partners, compared to 64.9 percent for male partners. ${ }^{60}$ The recession did not seem to greatly affect lawyers at this high level.

Even firms on the list of "50 Best Law Firms for Women"61 have not done much better. In 2007, women made up only 16 percent of their equity partners. ${ }^{62}$ However, the group has improved since then, and despite the recession, by 2011, 19 percent of their equity partners were women. 63

It is important to note that firms differ considerably with regard to the percentage of women who achieve equity partnerships. For example, the percentage of women equity partners in some law firm giants such as Milbank Tweed is low (7.6 percent), a bit up from 2003 when it was 6.9 percent, or Cadwalader, Wickersham \& Taft's 6.6 percent, down from 10.3 percent in 2003. ${ }^{64}$ At Wachtell, Lipton, Rosen \& Katz, the firm known for its small partnership and the highest profits per partner among the "American Lawyer 200" firms, the number of women in the equity partnerships dropped dramatically, from 12.3 percent to 7.7 percent. ${ }^{65}$ And in a study updating "glass ceiling issues" in major law

58. Andrew Lu, More and More Women are Becoming BigLaw Equity Partners, GREEDY Associates: THE FindLAW Legal Lifestyle \& CAREER Blog (Aug. 24, 2012, 5:44 AM), http://blogs.findlaw.com/greedy_associates/2012/08/more-woman-equity-partners-at-biglaw-firms.html.

59. Molly McDonough, NLJ Survey: Slow Progress for Women Partners in BigLaw, A.B.A. J., July 24, 2012, http://www.abajournal.com/news/article/nlj_survey_slow_progress _for_women_partners_in_biglaw_5_firms/.

60. James G. Leipold \& Judith N. Collins, The Demographics of Equity, NALP BULLETIN, Nov. 2011, http://www.nalp.org/demographics_of_equity.

61. As chosen by the National Association of Female Executives (NAFE) \& Flex-Time Lawyers, who pick from a self-selecting firm applicant pool.

62. NAFE \& FLEX-TIME LAWYERS, supra note 57 , at 6.

63. Id.

64. Vivia Chen, At Big Firms, Equity Gender Gap Continues, NAT'L L.J., (July 23, 2012), http://www.law.com/jsp/nlj/PubArticleNLJ.jsp?germane=1202563861081\&id=12025 63849769 .

65. Id. 
firms in New York conducted for the Association of the Bar of the City of New York in 1994, and published in the Fordham Law Review, Epstein found substantial discrepancies in progress between the firms studied almost ten years later. ${ }^{66}$

A firm's tier structure affects the advancement of women to equity partnership. Women are promoted to equity partnerships less frequently in two-tier and multi-tier firms than they are in one-tier firms. ${ }^{67}$ Before the recession, in 2008, women were faring worse in multi-tier firms than in one- and two-tier firms, constituting only 13 percent of equity partners. ${ }^{68}$ Furthermore, there were reports that women partners were being "de-equitized."69 However, since the recession, it appears that women are faring the worst at two-tier firms. In 2010 and 2011, only 14 percent of equity partners in two-tier firms were women, as compared with 18 percent in one-tier firms and 17 and 18 percent in multi-tier firms. ${ }^{70}$ However, this change may be because firms are taking advantage of the new multi-tier structure to promote more women to equity partnerships, albeit in a fixed-income position.

Perhaps more important than firm structure, however, is firm culture. Vivia Chen reports that at Wilmer, Cutler, Pickering, Hale, and Dorr, one of the twenty firms with the highest percentage of women equity partners, 23.2 percent of the equity partners are women. ${ }^{71}$ Women partners at Wilmer identify culture as the reason for their success, but they note that the supportive elements are hard to pinpoint. They involve informal mentoring and a general appreciation for and acceptance of women rather than formal policies and programs. Furthermore, the top twenty firms with the highest percentage of women equity partners are dominated by characteristics like being

66. Cynthia Fuchs Epstein, Robert Sauté, Bonnie Oglensky \& Martha Gever, Glass Ceilings and Open Doors: Women's Advancement in the Legal Profession, 64 FORDHAM L. REV. 291-449 (1995). See also Cynthia Fuchs Epstein, Women in the Legal Profession at the Turn of the Twenty-First Century: Assessing Glass Ceilings and Open Doors, $49 \mathrm{U}$. KAN. L. REV. 733, 745 (2001).

67. See Chen, supra note 64.

68. See NAWL 2008, supra note 50, at 10-11.

69. See, e.g., JOAN C. WILliamS \& VETA T. RICHARDSON, MinORITY CoRPorate

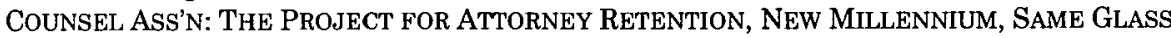
CEILING?: THE IMPACT OF LAW FIRM COMPENSATION SYSTEMS ON WOMEN 7 (2010).

70. Stephanie A. Scharf \& Barbara M. Flom, The NaT'l ASS'N OF WOMEN LaWyers \& THE NAWL FOUND., REPORT OF THE FIFTH ANNUAL NATIONAL SURVEY ON RETENTION AND PROMOTION OF WOMEN IN LAW FIRMS 13 (2010) [hereinafter NAWL 2010], available at http://nawl.timberlakepublishing.com/files/NAWL\%202010\%20Final(1).pdf; NAWL 2011, supra note 54, at 13 .

71. Chen, supra note 64. 
regional and highly specialized, highlighting other important factors that create a female-friendly culture..$^{72}$

\section{Fixed-Income Equity Partnerships}

Although fixed-income equity partners represent only 6 percent of all equity partners, ${ }^{73}$ it may be that firms created the category to improve their statistics on women partners and thus legitimize a subordinate status for women to whom they were not ready to grant full partnership status. Even when women reach equity partner status in multi-tier firms, they are much more likely to be fixed-income equity partners than men are. In fact, in 2011, 80 percent of all fixed-income equity partners were women, an increase of seven percentage points from $2010 .{ }^{74}$ The fixed-income equity partner status is not a starter placement or an intermediary stage before retiring: the majority of these women graduated law school in the 1980s or 1990s, meaning that they were at the peak of their careers. ${ }^{75}$

\section{Nonequity Partners}

Although NALP reports that "among women lawyers who are partners, there is not a dramatic skew towards non-equity status," only about half of the partners in the multi-tiered firms responded to the NALP survey question. ${ }^{76}$ This is important to note because according to the report, "anecdotally, the non-equity tier has been a traditional repository of women lawyers who advance to the equity level much less frequently than their male peers." 77 Firm structure matters here too. In 2008,27 percent of nonequity partners were women, but if one examines multi-tier firms, that percentage drops to 24 percent, possibly confirming our speculation that multi-tier firms are promoting women to fixed-income equity status rather than nonequity status. Disregarding firm structure, women constituted 26 percent of nonequity partners in 2007, and 27 percent in 2008 and 2009.78 In 2011, for the

72. Id.

73. NAWL 2010 , supra note 70 , at 14 .

74. See id. at 4, 14; NAWL 2011, supra note 54, at 4, 11.

75. See NAWL 2011, supra note 54, at 11-12.

76. See Leipold \& Collins, supra note 60.

77. The Nat'L Ass'N OF WOMEn LaWyers, a NAWL Report: National SuRvey on Retention and Promotion of WOMEn IN LAW FiRMS 5 (2007) [hereinafter NAWL 2007], available at http://nawl.timberlakepublishing.com/files/FINAL\%20survey\%20report\%2011 $-14-07 \% 20$ for $\% 20$ website.pdf.

78. See NAWL 2008, supra note 50; THE NAT'L Ass'N OF WOMEN LaWYerS \& THE NAWL Found., REPORT OF THE FOURTH ANNUAL NATIONAL SURVEY ON RETENTION AND 
first time since 2006, female nonequity partners decreased to 25 percent. ${ }^{79}$ While this decrease may seem minor, it can affect the future of women's leadership in firms. ${ }^{80}$ Even in the "best law firms for women" referred to earlier, women only constituted 28 percent of nonequity partners in 2011.81

\section{E. Lateral Partner Hiring}

While lateral hiring of partners was quite infrequent and negatively regarded in the past, lateral partner hiring is a growing phenomenon. ${ }^{82}$ Generally on a steady incline, lateral equity partner hiring increased by a substantial 21 percent from 2008 to 2009.83 This may be due to the fact that firms are more competitive about getting business, and they are hiring partners from other firms or corporate counsels who have strong business connections and personal relationships with clients.

Lateral movement has been a good strategy for both men and women, although men make up 85 percent of all lateral equity hires. ${ }^{84}$ Consistent with our previous discussion of firm structure, one-tier firms are much more likely to hire female equity partners laterally than are two-tier or multi-tier firms ( 25 percent versus 17 percent). 85

\section{F. Associates}

In recent history, women have progressively, but slowly, increased their numbers as associates, according to a NALP report. ${ }^{86}$ Their numbers continued to grow until 2009. However, in 2010, on the heels of the recession, there was a "dip" in female and minority associates for the first time in nearly twenty years. ${ }^{87}$ By 2011 , while minority numbers "have bounced back," female representation "declined further." 88 While the losses have slowed down, this report suggests that this could be the

\footnotetext{
Promotion of WOMEN IN LAW FIRMS (2009) [hereinafter NAWL 2009], available at http://nawl.timberlakepublishing.com/files/2009\%20Survey\%20Report\%20FINAL.pdf.

79. See NAWL 2011, supra note 54, at 3-5.

80. Id.

81. NAFE \& FLEX-TIME LAWYERS, supra note 57, at 6.

82. NAWL 2008, supra note 50 , at 14-15.

83. NAWL 2009, supra note 78 , at 13.

84. Id. at 14.

85. Id.

86. See Diversity Wobbles, supra note 16 .

87. Id.

88. $I d$.
} 
beginning of a "downward trend" for women. ${ }^{89}$ Numbers continued to fall in $2011 .{ }^{90}$

\section{G. Staff Attorneys}

Staff attorneys are full-time firm employees, but they are not on the partnership track. Therefore, they get less compensation, receive fewer desirable assignments and opportunities for professional development, and have a smaller chance for advancement. However, given associate terminations resulting from the recession, these positions are attractive to junior lawyers. ${ }^{91}$

Women make up 60 percent of staff or contract attorneys, those attorneys who are not on a partnership track and are not considered for promotion, the most interesting work opportunities, or increasing compensation. Contract attorney is the job title that includes the highest concentration of women in any area or practice of law. Further, there is some evidence that firms choose to hire women lawyers as staff attorneys rather than allow their full-time women attorneys to work a part-time schedule. ${ }^{92}$ However, this practice does not seem to be a result of the recession. These jobs are not being taken by recent graduates who are having trouble finding other options: almost all of these women graduated before 2007, including a large percentage who graduated ten to twenty years ago. Because women make up the majority of staff attorneys at firms, and, by definition, staff attorneys are relegated to a type of law firm "ghetto," staff attorney positions are a new vehicle through which women attorneys are relegated to the margins of law firms. Because these attorneys have little possibility for career advancement, firms are not investing in a large number of women attorneys. ${ }^{93}$ It is unclear whether women are recruited for this position or if they move there after a few years on the partnership track. ${ }^{94}$ There is concern that the staff attorney position will become the "pink ghetto."95

89. Id. at $1 \cdot 2$

90. Women and Minorities in Law Firms-By Race and Ethnicity, NALP BULLETIN, Jan. 2012, http://www.nalp.org/women_minorities_jan2012 [hereinafter Women and Minorities].

91. See NAWL 2010, supra note 70, at 8-10.

92. Id. at 4.

93. Elie Mystal, Biglaw Women Relegated to 'Pink Ghetto' (When They Can be Found At All), ABOVE THE LAW (Nov. 9, 2010, 3:30 PM), http://abovethelaw.com/2010/11/biglawwomen-relegated-to-pink-ghetto-when-they-can-be-found-at-all/.

94. See NAWL 2011, supra note 54, at 6 .

95. Chen, supra note 31 . 


\section{H. Of Counsel Positions}

In the past, of counsel positions were generally offered to lawyers as they made the transition to retirement. However, today, firms try to market their of counsel lawyers as having similar "skills, experience, and ability [to] young partners." 96 This position is often viewed as a "stepping stone" between associate and partner ${ }^{97}$ However, the position promises less opportunity for advancement and firm leadership, and then only some of counsel lawyers are considered for partnership..$^{98}$

In 2006, women constituted 28 percent of of counsel lawyers. ${ }^{99}$ That number has continued to rise, hovering between 34 and 36 percent from 2008 to 2011.100 Some believe that of counsel positions might be a "detour for women lawyers who have moved off the traditional partnership track with no 'on-ramp' back." ${ }^{101}$ Examining the numbers, this trend does not seem to be affected by the recession.

\section{Contract Attorneys}

Law firms do not employ contract attorneys, but, in a process analogous to outsourcing, they are hired through agencies for specific, time-limited projects. ${ }^{102}$ By utilizing contract attorneys, firms are hiring legal professionals who are willing to do work that is often monotonous and tedious. Firms do not find it necessary to educate and promote them. The firms benefit from having flexibility in hiring and can release contract attorneys at their discretion. These characteristics have made the use of contract lawyers very attractive during the recent recession, and they are currently "hot in demand." This affects women because there is some evidence that in addition to the use of staff attorneys, firms are also using contract attorneys rather than allowing their own women lawyers to work part-time. ${ }^{103}$

\section{J. Other Leadership Roles}

In other leadership roles, the average firm's management committee-its highest governing committee-includes only one or two

96. NAWL 2007, supra note 77 , at 6 .

97. NAWL 2011, supra note 54, at 2.

98. See id. at 2-3.

99. NAWL 2007, supra note 77 , at 6-7.

100. Id.

101. Id.

102. NAWL 2010 , supra note 70 , at 7 .

103. Id. at 11 . 
women, and 11 percent of the nation's largest firms have no women at all on their management committees. ${ }^{104}$ Further, the New York City Bar recently held a panel discussion to examine a perceived lack of women litigators acting as lead attorneys before New York's appellate bench. After reviewing many of their cases, the seven women judges on that panel found that women had argued or were lead attorney in only 19.3 percent of civil cases and 12.2 percent of commercial cases heard between September 2010 and January 2011.105 In its 2010 Report, NAWL found that women have become managing partners in very few firms, although a number of them were managing branch offices. ${ }^{106}$

\section{K. General Counsels in Large Corporations}

One cannot address the opportunities available to lawyers without examining recent changes in the corporate structure of the United States. Plunges in the economy have also led to high unemployment rates, a shaky housing market, and changes in consumer spending, a backdrop that must be considered in assessing the opportunities and job security of lawyers. After what has been described as the "delirious bubble" years of 2006-2007 and the epic collapse of 2008, massive earnings in 2009 returned Fortune 500 profits to the "normal" level. 107

The changes in the corporate structure of the United States have provided new opportunities for women attorneys. Ever-expanding legal departments in corporations have employed many women, and the number of women general counsels has increased substantially. Of course, many women moved to corporate legal departments from large firms where they either found the workload too onerous or where they had failed to become equity partners. This has long been the career trajectory of men in similar situations. Jobs as general counsel offer extremely high salaries (usually well over one or two million dollars), better time schedules, and no pressure to bring in business. Of course, such salaries, regarded as extremely high to most lawyers who are not in the top 100 law firms, are modest compared to salaries in the multiple millions that can be earned in the leading private firms.

104. See CORCORAN \& THERING, supra note 36 , at 9 .

105. Laura Haring, Panel Explores Reasons for Lack of Women Commercial Litigators, N.Y. L.J. (Mar. 7, 2011), http://www.newyorklawjournal.com/PubArticleNY.jsp?id=120248 4380681\&Panel_Explores_Reasons_for_Lack_of_Women_Commercial_Litigators.

106. NAWL 2010, supra note 70 , at 3.

107. MCCA 2010 Survey of Fortune 500 Women General Counsel, MinORITY CoRPORATE COUNSEL ASS'N, http://www.mcca.com/index.cfm?fuseaction=page.viewPage\&pageID=2107 (last visited Mar. 8, 2013) [hereinafter Fortune 500]. 
In 2010, ninety-four women served as top legal officers in Fortune 500 companies. The 2010 roster not only included eighty-two White women but also seven African Americans, three Hispanics, and two Asian-Pacific American women. ${ }^{108}$ Women also led the legal departments of the some of the best performing companies in the Fortune 500, such as Procter and Gamble. ${ }^{109}$ While the increase in the number of women in these positions is encouraging, law bloggers are quick to point out that women still only account for 20 percent of such positions, declaring that the "glass ceiling" is far from being broken. ${ }^{110}$

\section{PART-TIME WORK}

For some time, part-time work was seen as the answer to women's hopes for "work-family balance," a term now commonly used to describe a desirable life for women and sometimes for men. Far from the former model of the "Organization Man" with a stay-at-home wife who supported his career progress by tending to children and the household, the modern ideal is a family in which both husband and wife work, but not such long hours as to preclude time with children and other family activities. As is well-known, this work-life balance paradigm is most often oriented toward women rather than men.

Thus, part-time work in the legal profession became something of an ideal in the past several decades, supported by new organizations set up to provide information and orientation to part-time work. Although part-time work became institutionalized and seemed suitable for a subset of women (but hardly any men), a study by Epstein, Sauté, Oglensky, and Gever reported that only a tiny number of women lawyers actually worked as part-time partners in large firms, and there were career costs to the men and women who chose this path. ${ }^{111}$ Nevertheless, it was an option for some.

Overall, 98 percent of law firms offer some type of part-time or flex-time policy. In 2008, just 5.6 percent of attorneys were working part-time. ${ }^{112}$ of course, the vast majority of part-time attorneys are women. Only 2 percent of male lawyers worked part-time in 2008 , while

108. Id.

109. Id.

110. E.g. Andrew Lu, More Women General Counsels at Fortune 500 Companies Than Ever Before, In House: THE FtndLaw Corporate Counsel Blog (Sept. 4, 2012, 5:56 AM), http://blogs.findlaw.com/in_house/2012/09/more-women-general-counsels-at-fortune-500companies-than-ever-before.html.

111. See Epstein et al., supra note 66, at 392-414.

112. Press Release, NALP, Women Vastly Outnumber Men Among Part-Time Lawyers-Overall, Number of Lawyers Working Part-Time is Small, Rate Little Changed Over Time (Dec. 18, 2008), http://www.nalp.org/parttimelawyers. 
the overall percentage of women lawyers working part-time was 12.8 percent. ${ }^{113}$ The result is that 74 percent of part-time lawyers are women. ${ }^{114}$ The percentage of lawyers working part-time has steadily increased since the early 1990 s (when NALP began collecting data) and has always been heavily dominated by women. However, for the first time in seventeen years, NALP found that part-time work declined in 2011.115

This option of part-time work is used more often in certain cities: for example, part-time attorneys are twice as common in Washington, DC and Chicago than in New York City. ${ }^{116}$ The recent economic downturn, however, severely undermined the practice. For one thing, part-time positions have been reduced or replaced, severing the understandings and relationships between part-time and full-time lawyers in the firms. As reported by NAWL, men and women have been terminated at rates proportionate to their numbers as associates and partners, but the termination of part-time attorneys has been the exception. Even when controlling for the much larger number of women attorneys in part-time positions, from 2008 to 2010 women were fired from these positions in greater proportions than men. ${ }^{117}$

When law firms believed they were forced to compete for the best talent, they were willing to consider part-time work arrangements for incoming attorneys; today, as noted above, most part-time work is relegated to staff and contract attorneys. As the majority of part-time positions have been held by women, so are the positions of staff and contract attorney, and it is these attorneys who are being fired disproportionately more than full-time attorneys. Furthermore, in a time of recession, both women and men who had part-time employment in the past have experienced a reduction in opportunities for such work.

The issue of part-time work in the legal profession is complex. In recent years, it has been considered a woman's issue, but actually, in the past many men worked part-time as well. The difference was that, for women, part-time work was characteristic of the beginning and early stages of their career when they were having children, while for men, the practice was for the end of their career as they were slowing down. While these men had often proven themselves as rainmakers or specialists with a proven track record, many of the women seeking part-time employment are in a different structural position since they

113. Id.

114. Id.

115. Press Release, NALP, Part-Time Work Among Lawyers Declined for First Time in 17 Years (Jan. 19, 2012), http://www.nalp.org/part-time_jan2012.

116. CoRCORAN \& ThERING, supra note 36 , at 54.

117. NAWL 2011, supra note 54, at 15; NAWL 2010, supra note 70, at 17. 
usually have not had an opportunity to amass the human and economic capital ${ }^{118}$ that would give them leverage in the firms' accounting schemes of professional value.

\section{COMPENSATION}

Women lawyers as a whole are compensated less than their male peers. This gap persists even when comparing similarly-situated men and women, controlling for such factors as credentials and work profiles. ${ }^{119}$ But the gap has been lessening. According to the Bureau of Labor Statistics, the salary gap between men and women lawyers has decreased in recent times. In 2008, before the recent recession, women lawyers (in all kinds of practices) earned 80.5 percent of men's incomes, but this proportion has slipped since the recession, and, although the change is not large, one must remember that the number of women lawyers in many categories has diminished. ${ }^{120}$ Furthermore, it is probable that the figure does not include bonuses, which account for a large proportion of lawyers' incomes for those in private practice.

118. See generally Pierre Bourdieu, The Forms of Capital, in HANDBOOK OF THEORY AND RESEARCH FOR THE SOCIOLOGY OF EDUCATION 241-58 (John Richardson ed., 1986).

119. See Ronit Dinovitzer et al., The Differential Valuation of Women's Work: A New Look at the Gender Gap in Lawyers' Incomes, 88 Soc. FoRCES 819, 843 (2009).

120. A CURRENT GLANCE AT WOMEN IN THE LAW (2012), supra note 46 , at 6 . 
Female Lawyer's Salaries as a Percentage of Male Lawyer's Salaries ${ }^{121}$

\begin{tabular}{|l|l|}
\hline 2002 & $69.4 \%$ \\
\hline 2003 & $76.8 \%$ \\
\hline 2004 & $73.4 \%$ \\
\hline 2005 & $77.5 \%$ \\
\hline 2006 & $70.5 \%$ \\
\hline 2007 & $77.5 \%$ \\
\hline 2008 & $80.5 \%$ \\
\hline 2009 & $74.9 \%$ \\
\hline 2010 & $77.1 \%$ \\
\hline 2011 & $86.6 \%$ \\
\hline
\end{tabular}

The salary gap is affected by a number of factors. It is partially a reflection of the fact that there are a disproportionate number of women lawyers working in the not-for-profit sphere (such as public interest and government work). However, it also reflects the fact that, at every position in large firms, women get paid less than men. ${ }^{122}$ In 2010 , their average billing rate was $\$ 259$ an hour compared to men's rate of $\$ 312 .{ }^{123}$

121. Id.

122. NAWL 2011, supra note 54, at 3-4.

123. Erin Fuchs, Women Lawyers Less Valued, Lower Billing Rates Show, LAw360 (Apr. 11, 2011), http://nawl.timberlakepublishing.com/files/women\%20lawyers\%20less\%20value d\%20survey.pdf. 
Of course, in many top international corporate firms, partners' billing rates are closer to $\$ 1,000$ an hour. ${ }^{124}$ And it should not be a surprise to note that, in 99 percent of the largest law firms, a man is the highest compensated lawyer. ${ }^{125}$ The gap varies depending on the position one holds in the firm, with the largest gaps at the highest levels.

\section{A. Equity Partner Compensation}

In 2008, women equity partners earned 87 percent of what their male counterparts earned. ${ }^{126}$ Ironically, the gap diminished between 2008 and 2009, with the smaller gap likely an effect of reduced compensation at the equity level.127 As men were paid more to begin with, their compensation was reduced more than women's.

As the economy has improved, however, the gap has re-emerged or even enlarged. In 2010, women equity partners' compensation was 85 percent of men's compensation, and, in 2011, women earned 86 percent of what male equity partners made. ${ }^{128}$ Of course, quite a lot of sifting and sorting had occurred in which low-producing attorneys had been weeded out, and those left were the higher producing attorneys. Women are consistently doing better in one-tier partnerships than in two-tier or multi-tier firms. ${ }^{129}$

\section{B. Nonequity Partner Compensation}

The figures for nonequity partner compensation should be judged in the same way. Compensation among nonequity partners has become more equitable as a result of the recession. Among those in this category, in 2008, women made 91 percent of men's salaries. ${ }^{130}$ The gap narrowed to 94 percent in 2010 and 95 percent in $2011,{ }^{131}$ probably due to the decrease in the numbers of women in firms and the weeding out of the lower performers.

124. See Alex Vorro, Law Firm Billing Rates Steadily Climbing Despite Down Economy, INSIDECOUNSEL (Apr. 17, 2012), http://www.insidecounsel.com/2012/04/17/law-firm-billing -rates-steadily-climbing-despite-d.

125. NAWL 2009, supra note 78, at 10.

126. NAWL 2008, supra note 50, at 14.

127. NAWL 2009 , supra note 78 , at 11.

128. NAWL 2011, supra note 54, at 3; NAWL 2010, supra note 70, at 22.

129. NAWL 2007, supra note 77 , at 12 .

130. NAWL 2008, supra note 50, at 14 .

131. NAWL 2011, supra 54, at 17-18; NAWL 2010, supra note 70, at 21. 


\section{Associate Compensation and Lockstep Structure}

In 2008, before the effects of the recession were felt, female associates earned 97 percent of what male associates earned. ${ }^{132} \mathrm{~A}$ major reason for gender parity at the associate level is lockstep compensation-whereby firms pay all associates of the same class equally. However, this practice has changed. Now, only 27 percent of firms use true lockstep (salary and bonus) for their first-year associates, while only 9 percent of firms have used this system for all their associates. ${ }^{133}$ Some see the decline in lockstep as a positive move, allowing firms to "reward lawyers based on performance rather than seniority."134 However, others see it as detrimental to relationships among colleagues within law firms. ${ }^{135}$ Furthermore, women do better in firms that employ the lockstep structure, for it "minimizes subjective factors in evaluation of associates, including gender-based distinctions." 136 There is no significant difference between what firms pay male and female associates, regardless of whether or not they use a lockstep system. However, a review of bonuses shows that women do not get their fair share in both lockstep and nonlockstep firms, and they fare even worse in nonlockstep firms. ${ }^{137}$ Overall, female associates receive bonuses that are 6-8 percent lower than their male colleagues. ${ }^{138}$ These discrepancies may be because bonuses leave a lot of room for "discretion that permits gender-biased decision making." 39 Since the recession, many firms have eliminated lockstep compensation, which may aggravate gender disparities.

\section{Of Counsel Compensation}

Overall, the compensation gap between of counsel men and women has hovered around 90 percent for a number of years, seemingly unaffected by the recession. ${ }^{140}$

132. NAWL 2008, supra note 50, at 14.

133. NAWL 2011, supra note 54, at 8.

134. Carlyn Kolker, Pay Structures Take Hit at U.S. Law Firms, GLOBEADVISOR.COM (Mar. 18, 2009), https://secure.globeadvisor.com/servlet/ArticleNews/story/gam/20090318/ PAYSTRUCTURE18.

135. Sterling \& Reichman, supra note 2, at 2294-95.

136. NAWL 2011, supra note 54, at 7.

137. Id. at 8 .

138. CORCORAN \& THERING, supra note 36 , at 6 .

139. NAWL 2011, supra note 54 , at 8.

140. See id. at 17; NAWL 2008, supra note 50, at 14 . 


\section{FIRING AND HIRING}

\section{A. Female Terminations Due to the Recession}

Almost all firms have terminated lawyers as a result of the economic downturn. ${ }^{141}$

The 2009, 2010, and 2011, surveys of the nation's 200 largest law firms conducted by NAWL indicated that the rates of female termination occurred at approximately the same rate as men in the positions they held.142 Junior positions bore the brunt of the terminations. ${ }^{143}$ Since women are overrepresented in lower-ranked positions, they were the most likely to be eliminated. Therefore, as women started to get through the glass ceiling, the recession complicated their voyage with many problematic turns and dead ends. During the years right after the downturn in the economy, from 2009 to 2011 , about 75 to 80 percent of those laid off were associates. ${ }^{144}$ In the nation's 250 largest firms, the average number of women associates per firm fell from 124.7 to 112.145 The NALP Foundation found that in 2010, female associate departures and attrition were greater than for their male counterparts. ${ }^{146}$ However, things may be improving. According to NAWL, women comprised 38 percent of terminated associates in 2011 , which was "fewer than expected." 147

There are serious limitations to some of this data because many firms refuse to answer questions about the gender division of lawyers who have been laid off. Furthermore, there is great variability among the firms who did answer the questions; some firms laid off only 5 percent of their women, while others terminated women exclusively. ${ }^{148}$ The legal press reported some particularly egregious examples of how the recession hurt women and minorities in particular firms. For

141. NAWL 2009, supra note 78 , at 14.

142. See id. at 15; NAWL 2011, supra note 54, at 14; NAWL 2010, supra 70, at 16.

143. See generally Chris Mondics, As Clients Call Shots, Law Firms Cutting Jobs, PhILly.com (Mar. 22, 2009), http://articles.philly.com/2009-03-22/business/24984056_1_ law-firms-lawyers-and-other-staff-young-lawyers; Carol J. Williams, Law Firms Give Associates a Chance to Build Skills While Doing Good, L.A. TIMES (Apr. 6, 2009), http://articles.latimes.com/2009/apr/06/local/me-loaner-lawyers6.

144. See NAWL 2011, supra note 54, at 13; NAWL 2009, supra note 78, at 14; NAWL 2010, supra note 70 , at 16.

145. Tresa Baldas, Bad Times Could Have Been Worse for Women, NAT'L L.J., Nov. 30, 2009 , at 12 .

146. See Carolyn Elefant, Are Female Lawyers at Risk in a Recession?, LAw.CoM (Feb. 24, 2009, 3:35 PM), http://legalblogwatch.typepad.com/legal_blog_watch/2009/02/are-wome n-lawyers-at-risk-in-a-recession.html.

147. NAWL 2011, supra note 54, 13.

148. NAWL 2009 , supra note 78 , at 15. 
example, in 2009, the attrition rate in the Washington D.C. office of Kirkland \& Ellis was 27 percent for women, but zero for men. ${ }^{149}$ And in the same year in the Atlanta office of Womble Carlyle, fewer than 8 percent of male associates, but 50 percent of female associates, left during the same period. 150

Terminations of equity partners seem to reflect a gender bias. As we noted above, there are very few women equity partners compared to men. But in 2008, 50 percent of the equity partners who were terminated were women. ${ }^{151}$ By 2009 , almost no female equity partners were laid off, 152 perhaps because the few who were left were quite valuable to their firms. Of course in hard times, the firms look to retain their rainmakers and women make up only a minority of rainmakers. A 2010 report by NAWL showed that 46 percent of firms in their sample reported no women among their top ten rainmakers. ${ }^{153} \mathrm{~A}$ recent study by Joan Williams and Veta Richarson reported that female partners are in fact being systematically excluded from rainmaking opportunities, and when they are included in "client pitches," they are not receiving their fair share of financial benefits. ${ }^{154}$ Finally, all equity partners, including women, fared better in one-tier firms, for these firms terminated fewer lawyers during the recession. ${ }^{155}$

Other reports indicate that the recession could have been a lot worse for women. According to the National Law Journal's 2009 survey of the nation's 250 largest law firms, the number of women lawyers at those firms decreased by 2 percent, whereas the overall loss of both men and women lawyers was 4 percent. ${ }^{156}$ Those firms that continue to place a high priority on diversity and retention had the smallest decreases in women lawyers, while the type of law they practiced also played a role. ${ }^{157}$

\section{B. Summer Associates Hiring}

Summer associate positions are a good indicator of opportunity and the health of the profession. Summer jobs are a gateway to jobs at firms

149. Elie Mystal, Diversity Issues to Consider Before You Accept Your Offer, ABovE THE LAW (Nov. 8, 2010, 6:10 PM), http://abovethelaw.com/2010/11/diversity-issues-to-considerbefore-you-accept-your-offer/.

150. Id.

151. NAWL 2009, supra note 78 , at 15.

152. Id.

153. NAWL 2010, supra note 70 , at 3 .

154. WILLIAMS \& RICHARDSON, supra note 69 , at 7.

155. NAWL 2011, supra note 54, at 13; NAWL 2010, supra note 70, at 13.

156. See Baldas, supra note 145.

157. Id. 
in both private sector and public interest firms. In fact, in the current economic environment, there is not much third-year law student hiring, amplifying the pressure to become a summer associate after the second year. ${ }^{158}$ Fortunately, the proportion of women summer associates is comparable to the proportion of women in law school. ${ }^{159}$ In $2011,47.7$ percent of summer associates were women. ${ }^{160}$ In the wake of the recession, overall summer associate class sizes hit a historic low. Some firms even eliminated or suspended their summer associate programs altogether. ${ }^{161}$ In 2010 , many firms reduced the number of summer associates they took on. In 2011, NALP reported that the median number of summer associate offers made by firms was ten (46.4 percent of their interviewees), up from nine in 2010 (40.6 percent of their interviewees), but still far below the pre-recession number of 16 (60 percent of their interviewees). ${ }^{162}$ The average class size was eight in both 2011 and 2012, a historic low. In 2011, firms spent more money on recruitment than in the past couple of years, but they did not bounce back to pre-2008 levels. ${ }^{163}$ While this can be viewed optimistically, NALP Executive Director James Leipold stated that "[t]he days of the large summer classes are over. And they're not coming back."164 Today's low summer associate numbers are significant because they indicate that firms do not plan to increase hiring for at least two years, as that is the time frame used by most firms. ${ }^{165}$

\section{Female Hiring During the Recession}

While firms made offers for summer jobs to fewer law school students in 2011 and 2012 than they had in the past, of those who had these summer jobs, the likelihood of being hired at the firms for which they are working remained high- -91.4 percent of summer associates

158. See Karen Sloan, Summer Associate Hiring Lackluster as New Norm Sets In, NAT'L L.J., (Mar. 7, 2012), http://www.law.com/jsp/nlj/PubArticleNLJ.jsp?id=1202544709129\&sl return=1. Cf. Elie Mystal, NALP 2012: Does Your School Even Know How to Get You a Small Firm Job?, ABOVE THE LAW (Apr. 23, 2012, 5:00 PM), http://abovethelaw.com /2012/04/nalp-2012-does-your-school-even-know-how-to-get-you-a-small-firm-job/.

159. See Diversity Wobbles, supra note 16 , at 2.

160. Women in Law, supra note 44, at 3.

161. See Williams, supra note 143.

162. See Sloan, supra note 158.

163. Id.

164. Elie Mystal, NALP 2012: Good News, We've Probably Hit the Bottom, ABove THE LAW (Apr. 19, 2012, 10:09 AM), http://abovethelaw.com/2012/04/nalp-2012-good-news-we ve-probably-hit-the-bottom/.

165. See Sloan, supra note 158. 
were hired in $2012 .{ }^{166}$ This was probably due to the high selectivity process.

Otherwise, the hiring landscape has not looked as bright. After hiring reached a twenty-year high in 2007 at 91.9 percent of summer associates, law school graduates in 2010 faced the lowest proportion hired in fourteen years with 87.6 percent employed. ${ }^{167}$ While this number might not seem low, it was the lowest in fifteen years. ${ }^{168}$ Things have continued to get worse. Although the economy is rebounding, law schools sent a smaller percentage of 2011 classes to first-year associate jobs in large law firms than they did in 2010: 22 percent, down from 27 percent. ${ }^{169}$ In fact, the rates of graduates employed in academic positions were at an all-time high of 3.5 percent in 2009. ${ }^{170}$ This is most likely the law schools hiring their own graduates. It can be understood as law schools helping their graduates in a bad economic climate, or it can be viewed skeptically, as a way for schools to artificially inflate their employment statistics so that U.S. News and World Report's annual law school survey would use the statistic to improve their ranking. The recent decrease in employment rates may also reflect the fact that, in 2009 and 2010, law graduates accepted temporary employment at very high levels, and they also accepted more part-time work or jobs that do not require a J.D. ${ }^{171}$

In 2010, 48 percent of new hires in firms were women, according to responses to the NALP survey question about the gender breakdown of new hires. 172 This was an increase of 5 percent from 2009. ${ }^{173}$ Women were hired at slightly better rates at the largest law firms (50 percent of their new hires) and slightly worse rates at smaller law firms (43 percent of new hires) in $2010 . .^{174}$ However, small firms were even more inequitable in 2009, when only 36 percent of their new hires were women. ${ }^{175}$

166. Id.

167. Press Release, NALP, Class of 2010 Graduates Faced Worst Job Market Since Mid-1990s: Longstanding Employment Patterns Interrupted 1 (June 1, 2011), http://www.nalp. org/2010selectedfindingsrelease [hereinafter 2010 Graduates].

168. See id.

169. Sloan, supra note 43.

170. Press Release, NALP, Market for Law Graduates Changes with Recession: Class of 2009 Faced New Challenges 3 (July 22, 2010), http://www.nalp.org/uploads/Class_of_09_ Jobs_and_JDs_Report_Press_Release.pdf [hereinafter Market for Law Graduates].

171. See id. at 2-3; 2010 Graduates, supra note 167 , at 1-2.

172. Cynthia Spanhel \& Tammy Patterson, The NalP Found. for Law Career RESEARCH \& EDUC., UPDATE ON ASSOCIATE ATTRITION (CALENDAR YEAR 2010) 7 (2011).

173. Id.

174. Id.

175. Id. 


\section{MINORITY WOMEN}

It is important to examine how women attorneys from minority groups have been affected by the recession, for their position at the intersection of both gender and racial disadvantage warrants special attention. According to NALP Executive Director James Leipold:

It is clear that the overlap of race and gender is significant, and presents unique hurdles for minority women in the law firm setting. Despite the fact that minority women outnumber minority men in law schools, minority women continue to leave law firms at a faster pace than their male and non-minority peers, often to pursue legal careers that are not law firm based. 176

The economic downturn has led to a small but significant decrease in the number of minority women attorneys in law firms. Dean Phoebe Haddon of the University of Maryland School of Law (the school's first African-American dean) has noted that the recession has had an impact on the pipeline of minority law students. ${ }^{177}$ Not only does she fear that the institutions will "retreat from efforts to diversify the profession," but also that "[ $t]$ he recession will also likely affect the availability of resources for less privileged students, disproportionately having an impact on minority students." 178

The overall representation of women and minority associates declined slightly from 2009 to 2010 , a change NALP describes as a casualty of massive layoffs due to the economic downturn.179 In 2011, firms made up for some of their minority loses, but have yet to return to pre-recession diversity levels. Examining the numbers more carefully "reveals that ... the bounce-back can be attributed entirely to an increase in Asian associates." 180 Throughout this tumultuous time, the percentage of minority women in law firms has remained rather flat,

176. Press Release, NALP, Law Firm Diversity Demographics Show Little Change, Despite Economic Downturn: Representation in Some Markets Declines While Others Show Small Gains 1 (Oct. 21, 2009), http://www.nalp.org/uploads/PressReleases/09NALP WomenMinoritiesRel.pdf.

177. First Ladies of Law, DIverse: Issues IN Higher Educ. (Apr. 16, 2009), http://diverseeducation.com/article/12495/.

178. Id.

179. Women and Minorities, supra note 90. See also Paul Oyer \& Scott Schaefer, What Drives Turnover and Layoffs at Large Firms? (March 2, 2010) (unpublished manuscript) (on file with author).

180. Id. 
hovering at just over 6 percent (6.23 percent in 2011, 6.20 percent in 2010 , and 6.33 percent in 2009). ${ }^{181}$

Minority women are also underrepresented in the highest ranks of firms of all sizes and in all regions. In 2011, 2 percent of all partners at the nation's largest firms were minority women, ${ }^{182}$ which is actually a slight increase from 2010 (1.95 percent). ${ }^{183}$ Minority women are better represented at the associate level, hovering around 11 percent since 2009 (10.96 percent in $2011,10.90$ percent in 2010 , and 11.02 percent in 2009). ${ }^{184}$ Diversity, however, is taking a hit because of the recession. The recession's major effect on minority lawyers, confirmed through Vault/MCCA data, ${ }^{185}$ has been a topic of concern among legal bloggers. ${ }^{186}$ One extreme example of the recession's disproportionate impact on minority lawyers, cited in Above the Law, occurred in the Washington D.C. firm, Baker Botts. There, from 2009 to 2010, the percentage of white associates decreased by 2 percent while the percentage of minority associates decreased by 27.3 percent. ${ }^{187}$

\section{A. Law Firm Structure's Effect on Minority Women}

One-tier firms are more beneficial to minority women, just as they are for all women: "In general, one-tier firms are more likely to be above the median percentage in having minority women lawyers (67 percent vs. only 39 percent for two-tier firms)." 188

181. Diversity Wobbles, supra note 16 , at 1.

182. Women in Law, supra note 44.

183. Diversity Wobbles, supra note 16 , at 1 .

184. Id. at 2.

185. See Vault.com and MCCA Release Latest Law Firm Diversity Survey Results: Statistics Reveal that Minority Lawyers Greatly Affected by Recession Cutbacks; Women Make Gains as Partners and Law Firm Leaders, VAULT (Sept. 29, 2010), http://www.vault. $\mathrm{com} / \mathrm{wps} / \mathrm{portal} / \mathrm{usa} /$ aboutvault/for-media/Vault/MCCA-Law-Firm-Diversity-Database-

Reveals-Recessions-Impact-on-Diversity-in-the-Legal-Industry?id=12 [hereinafter Recession Cutbacks].

186. See, e.g., Sonia M. Pedraza \& Michelle L. Querijero, Diversity in "The New Normal," Young AdvocATES, (ABA Section of Litig., Young Advocates Comm., Chi., Ill.), Winter 2012 , at 14 , available at http://www.americanbar.org/content/dam/aba/uncatego rized/litigation-youngadvocates-winter2012-mo.authcheckdam.pdf; Karen Sloan, Findings Confirm Fears for Minority Hiring by Law Firms, CoRP. CoUnS., (Oct. 4, 2010), http://www.law.com/corporatecounsel/PubArticleCC.jsp?id=1202472804486\&Findings_Co nfirm_Fears_for_Minority_Hiring_by_Law_Firms.

187. Mystal, supra note 149.

188. NAWL 2010, supra note 70 , at 13 . 


\section{B. Minority Women's Mobility}

Minority women have slightly lower mobility than others in their cohorts during the first two years of their careers (overall men had more mobility than women during this time period). ${ }^{189}$ Moreover, white women and minority women are more likely than men to be looking for new jobs after two years at law firms, possibly because they were not as mobile as their male counterparts earlier in their career. ${ }^{190}$

\section{Diversity Programs}

In this recession, any programs or initiatives that are expensive and are not generating income are on the chopping block. That is the major threat to law firm diversity stemming from the recent economic downturn, as diversity programs and personnel are being scaled back. Due to downsizing and the re-shifting of focus onto profit-generating efforts, the momentum firms had been exhibiting toward reaching levels of diversity more in line with U.S. society at large has slowed. ${ }^{191}$ Women of color in law firms have noticed this and have "perceived a lack of commitment from senior leadership towards [the] promotion of diverse candidates." 192

\section{Minority Women's Attrition}

Women tend to leave law firms earlier than men. In fact, "nearly half had left by the end of the third year." 193 This trend has continued throughout the recession. ${ }^{194}$ Furthermore, this is amplified at the higher levels in the law firm; there is a "gradual erosion of women highest with seniority," and " $[t]$ his trend has not changed dramatically in a number of years despite the very substantial number of women law graduates who entered firms in the last twenty years." 195

189. See Gita Z. WILDER, NALP \& THE NALP Found. FOR LAW CAREER RESEARCH \& EDUC., ARE MINORITY WOMEN LAWYERS LEAVING THEIR JOBS?,10 (2008), available at http: //www.nalp.org/assets/1280_ajdminoritywomenmonograph.pdf.

190. Id. at 12 .

191. The recession had an impact on minorities, including no increase in the percentage of minority equity partners and decreasing minority recruitment at all levels. See Diversity at Law Firms in the Post-Recession Era, JDSUPRA LAW NEWS (May 6, 2013), $\mathrm{http}: / / \mathrm{www}$.jdsupra.com/legalnews/diversity-at-law-firms-in-the-post-reces-27930/.

192. Women in Law, supra note 44 , at 12.

193. WILDER, supra note 189 , at 5.

194. See NAWL 2011, supra note 54, at 5-6.

195. NAWL 2009 , supra note 78 , at 7 . 
There is evidence that minority women leave in higher proportions than any other group. ${ }^{196}$ Despite the fact that minority women outnumber minority men in law schools, they continue to leave law firms at higher rates than their minority male and white peers. Often, these women leave in pursuit of legal careers that are not based in law firms. It is necessary for firms to conduct exit interviews to understand why these women are leaving and what the firm could have done better to keep them. ${ }^{197}$ The high percentage of minority attrition contradicts the seemingly stable minority statistics reported by law firms. This has caused some to wonder if there is simply a revolving door; minorities seem to have short life spans at these firms, but the firms keep their numbers constant by replacing them with other minorities. ${ }^{198}$

Minority women in law firms often do not feel their superiors are interested in their development and they wish they would receive more feedback on their work. ${ }^{199}$ However, when these complaints surface on legal blogs such as Above the Law, commenters are quick to argue that young lawyers, regardless of race or gender, rarely feel that the firms for which they work invest in them enough.

According to Gita Wilder, minority women in law firms commonly report that they are dissatisfied with their assignments for a variety of reasons discussed below. Asian females are the least satisfied. ${ }^{200}$ All female minorities (with the exception of Native Americans) were less satisfied than men of their background with their decision to become a lawyer. ${ }^{201}$ This satisfaction is not mainly related to salary, but rather to the nature of work these women are assigned. Unlike their white and male counterparts, minority women have fewer opportunities to travel for work, to handle matters entirely on their own, and to formulate strategy. ${ }^{202}$ Rather, they report that they are assigned to do mainly routine tasks. ${ }^{203}$ This contributes to the high rate of attrition of minority women in law firms. However, according to many law blog commenters, young lawyers rarely are truly satisfied with their assignments, and

196. See Recession Cutbacks, supra note 185.

197. See Nilesh Patel, Maintaining Diversity Efforts in this Economy, NAT'L L.J. (Jan. 31, 2011), http://www.law.com/jsp/nlj/PubArticleNLJ.jsp?id=1202479662075\&Maintaining _diversity_efforts_in_ this economy (suggesting that exit interviews should be "[a]n integral part of the administrative processes in place when an associate resigns").

198. See Bryant G. Garth \& Joyce Sterling, Exploring Inequality in the Corporate Law Firm Apprenticeship: Doing the Time, Finding the Love, 22 GEO. J. LEGAL ETHICS 1361, 1380 (2009).

199. See Women in Law, supra note 44, at 12.

200. WILDER, supra note 189, at 20.

201. Id.

202. Id.

203. Id. 
they claim that minority women perceive discrimination that does not exist. ${ }^{204}$

\section{E. Demand}

In spite of the perceived feeling of discrimination, women lawyers from minority backgrounds also benefit from client insistence on having minority lawyers represented in the legal teams that work on their matters. This demand continues to be a driving force in retaining and increasing diversity at law firms. ${ }^{205}$ In addition, incoming and laterally-hired attorneys at law firms are also beginning to care whether they go to work at a diverse firm. ${ }^{206}$

\section{WOMEN IN THE JUDICIARY}

It does not appear that the representation of women in the judiciary has been affected by the recession. They continue to constitute a minority of all judges, around 25-35 percent, depending on the type of court, but their numbers have remained fairly stable before, after, and during the recession. ${ }^{207}$

\section{CONCLUSION}

The recession does not "explain either the uneven progress made by women lawyers compared to their male counterparts" or "the backward slide of gender equity in law firms," according to NAWL. ${ }^{208}$ In this paper, we have identified a number of areas in which the recession has disproportionately affected women. We have further noted how the reconfiguration of the legal profession in the United States (as well as in certain countries abroad), which has been happening at the same time,

204. See generally ABOVE THE LAW blog comments.

205. See Michael Tierney, The Recession's Impact on Law Firm Diversity, DAILY REP. (Aug. 4, 2010), http://www.dailyreportonline.com/PubArticleDRO.jsp?id=1202464222206.

206. SPANHEL \& PATTERSON, supra note 172.

207. See GLANCE 2011, supra note 23, at 4; ABA COMM'N ON WOMEN IN THE Profession, A CURRENT GLANCE AT WOMEN IN THE LAW 2009, at 3 (2009), available at http://www.americanbar.org/content/dam/aba/migrated/women/reports/CurrentGlanceStat istics2009.authcheckdam.pdf; ABA COMM'N ON WOMEN IN THE PROFESSION, A CURRENT GLANCE AT WOMEN IN THE LAW 2008, at 3 (2008), available at http://www.american bar.org/content/dam/aba/migrated/women/reports/CurrentGlanceStatistics2008.authcheck dam.pdf; GLANCE 2007, supra note 22, at 3; CTR. FOR WOMEN IN GOV'T \& CIVIL SOC'Y, WOMEN IN FEDERAL AND STATE-LEVEL JUDGESHIPS 1 (2010).

208. NAWL 2011, supra note 54, at 1. 
has continuing consequences for women's equality in the legal profession.

Many changes in firm culture and structure (e.g. the increase of two-tier and multi-tier partnerships, the increase in lateral hiring, and the decline in lockstep compensation) and financial pressures exacerbated since the recession have disadvantaged women lawyers in terms of status and compensation.

This paper focused on changes to women's status in the legal profession after the precipitous financial downturn in 2008 sent markets plunging and left the economy in disarray. In the past four years, the opportunity structures within the legal profession have reflected market changes, although certain segments of it were protected by the need for legal services in the economy's sorting out process; moreover, recovery now seems to be certain in some segments of the marketplace, and the culture of the profession no longer tolerates the prejudices against women that were characteristic of it in the past. Changes during this volatile time may result in new institutional patterns in the profession, or the old prejudices may re-emerge as lawyers face a more competitive marketplace for their work and less predictable career paths. 